\title{
WHO BECOMES A SELF-EMPLOYED? THE CASE OF LITHUANIA
}

\author{
Gražina Startiené $\dot{1}^{1}$ Rita Remeikiené $\dot{2}^{2}$ \\ ${ }^{1}$ Kaunas University of Technology, Lithuania, grazina.startiene@ktu.lt \\ ${ }^{2}$ Kaunas University of Technology, Lithuania; rita.remeikiene@ktu.lt \\ cross $^{\text {ref }}$ http://dx.doi.org/10.5755/j01.em.17.1.2288
}

\begin{abstract}
The article is aimed to establish which form of employment - the employees or the unemployed were more inclined to seek for self-employment in Lithuania during the period of 1998-2010. The results of the calculations revealed that there exist strong links between the number of the employees and the selfemployed and the number of the unemployed and the self-employed which proposes that both forms of employment have opportunities to change their employment status and become the self-employed, creating new value and contributing to the reduction of unemployment rate as well as GDP development. Calculated values of determination coefficients propose that the number of the employees and the self-employed $\left(\mathrm{R}^{2}=\right.$ $0.79)$ correlate stronger than the number of the unemployed and the self-employed $\left(R^{2}=0.54\right)$. In Lithuania, self-employment is treated as an alternative to escape unemployment but not as an opportunity to find new business niches or implement one's dreams. From this point of view, Lithuania can be treated as the country where entrepreneurship is influenced by external factors (unemployment, income loss) more than by internal factors (implementation of the objectives, aims and so forth).

Keywords: self-employment, self-employed persons, unemployed persons, employees.

JEL Classification: L26, E624.
\end{abstract}

\section{Introduction}

According to Pukeliene \& Starkauskiene (2011), one of the most important factors determining quality of life is income to be received from different sources. Utility maximization theory (Lofstrom, 2002; Hammarstedt, 2004; Georgellis, Wall, 2005; Fölster, 2000) states that a person will choose self-employment only if it gives the person the maximum benefit, i.e. an individual tends to compare the expected income from self-employment with the state benefits and earning, and choose the most acceptable alternative that assures the maximum revenue. The scientific literature (Tervo, 2008; Blume, et al. 2009, and others) analyzes the relationship between paid employment / unemployment / self-employment; the scientists provide not only financial reasons explaining why employment status of a person in the labour market has been changed and self-employment has been started-up, but also indicate other factors that promote selfemployment: discrimination in the labour market, prevailing high unemployment rate in a country, unfavourable microclimate, psychological discomfort in employed work.

The literature analyzed ("push" and "pull" schools; Ritsilä, Tervo, 2002; Muehlberger, 2007; Verheul et al., 2006; Carree et al., 2007; Parker, 2004; Johansson, 2000) often argued that the potential of selfemployment are unemployed people who become the self-employed due to limited opportunities in the labour market. The unemployed people are encouraged to start-up their own business by employment promotion programs in various countries (French and Lithuanian programmes designed to encourage the unemployed to become entrepreneurs and others). Both scientific literature and employment promotion programs lack the analysis of the opportunities for the employed people to seek for self-employment.

Purpose - identification of the potential of employed and unemployed people to become the selfemployed.

\section{Objectives:}

1) with reference to the scientific literature, to systematize the reasons why employed and unemployed people start-up business;

2) to analyze statistical data of the activity of Lithuanian population (the employed, unemployed and self-employed) in Lithuania during the period of 1998-2011.

3) using mathematical statistical methods, to evaluate the opportunities for the employed and unemployed to seek for self-employment during the period of 1998-2010 (the case of Lithuania).

Research methods: systematic comparative analysis of the scientific literature, the method of crosscorrelation analysis, Pearson's correlation coefficient, determination coefficient, statistical data analysis.

According to the results of the conducted research, the first part of the article is designed to systematize the reasons why employed and unemployed people start-up business. It has been found that the employees are often "pushed" while the unemployed are "pulled" into self-employment (classification made with reference to "push" and "pull" theories). The second part of the article analyzes statistical data of the 
activity of Lithuanian population (the unemployed, employees and self-employed) during the period of 19982011. The third part of the article is designed for the empirical study that, using Pearson correlation, determination coefficient and cross-correlation techniques, helps to determine representatives of which form of employment (the unemployed or the employees) have greater opportunities and potential to become the self-employed.

Keywords: self-employment, self-employed people, unemployed people, employees.

JEL Classification: L26, E624.

\section{What reasons encourage to seek for self-employment?}

Motivation towards self-employment is highly multidimensional. The analysis of the scientific literature has revealed that there are many different reasons encouraging a person to start self-employment. Some scientists (Dawson, Henley, Latreille, 2009; Hessels, Gelderen, Thurik, 2008; Binder, Coad, 2012) are inclined to classify the reasons of self-employment start-up into the following categories: self-employment out of necessity or necessity motives, self-employment out of the opportunity, lifestyle decision or independence motive and occupational choice. Other authors (Jacobs, 2007; Muehlberger, 2007; Carree et al. 2007; Parker, 2004; Georgellis, Sessions, Tsitsianis, 2005 and others) base the aspiration of a person to become self-employed on economic (mainly pursuit of financial gain) and social - psychological (lack of favourable microclimate, discrimination in the labour market and so forth) factors of self-employment. Another group of scientists (Thurik et al., 2008; Cassar, 2007) are inclined to classify the reasons of selfemployment start-up into the forces of "push" and "pull". Although there are numerous scientific studies to analyse the reasons of self-employment start-up, unfortunately, there still is a lack of the research to reveal the reasons of self-employment according to particular status of an individual in the labour market, i.e. what reasons determine an unemployed person or an employee ${ }^{1}$ to act independently in the labour market by starting-up his own business. The analysis of the results of different research enabled to systematize the reasons for self-employment when it is started-up by the unemployed and the employee (see Table 1).

Table 1. The reasons for self-employment start-up by the employment status

\begin{tabular}{|c|c|c|c|}
\hline Author & $\begin{array}{l}\text { Start-up by the } \\
\text { unemployed }\end{array}$ & Author & Start-up by the employee \\
\hline $\begin{array}{l}\text { Hammarstedt, } 2009 \\
\text { Clark, Drinkwater, } \\
\text { 2010; Ritsilä, Tervo, } \\
\text { 2002, Muehlberger, } \\
\text { 2007, Verheul and et. } \\
\text { al., 2006; Carree and } \\
\text { et. al., 2007; Parker, } \\
\text { 2004; Johansson, } 2000\end{array}$ & $\begin{array}{l}\text { - Obstacles in the } \\
\text { labour market } \\
\text { searching for a paid } \\
\text { work; } \\
\text { - } \\
\text { - } \\
\text { Liscrimination; } \\
\text { Loss of income. }\end{array}$ & $\begin{array}{l}\text { Shane, Locke, \& Collins, } \\
\text { 2003; Evans and } \\
\text { Jovanovic, 1989; Evans } \\
\text { and Leighton, 1989; } \\
\text { Dunn and Holtz- } \\
\text { Eakin, 2000; Benz and } \\
\text { Frey, 2004, } 2008\end{array}$ & $\begin{array}{ll}- & \text { Autonomy; } \\
\text { - } & \text { Personal profit; } \\
\text { - } & \text { Familial wealth. }\end{array}$ \\
\hline $\begin{array}{l}\text { Andersson, Wadensjö, } \\
\text { 2007; Caliendo, } \\
\text { Kritikos, 2010; } \\
\text { Berzinskiene, } \\
\text { Juozaitiene, } 2011 \\
\end{array}$ & $\begin{array}{l}\text { Subsidies for } \\
\text { business start-up } \\
\text { (e.g. start-up subsidy, } \\
\text { bridging allowance } \\
\text { in West Germany). }\end{array}$ & $\begin{array}{l}\text { Cassar, 2007; Elfenbein } \\
\text { et. al., 2010; Binder, } \\
\text { Coad, } 2012\end{array}$ & $\begin{array}{ll}- & \text { Recognition of opportunities; } \\
- & \text { Work in a micro-enterprise; } \\
- & \text { Work in the environment which } \\
& \text { encourages entrepreneurship. }\end{array}$ \\
\hline \multirow[t]{3}{*}{$\begin{array}{l}\text { Caliendo, Kritikos, } \\
2009\end{array}$} & $\begin{array}{l}\text { Advice/incentives } \\
\text { by the unemployed } \\
\text { who have become } \\
\text { self-employed. }\end{array}$ & Uusitalo, 2001 & $\begin{array}{l}\text { Psychological factors (optimism, } \\
\text { sense of happiness). }\end{array}$ \\
\hline & & $\begin{array}{l}\text { Milán and etc., 2011; } \\
\text { Kawaguchi, } 2008\end{array}$ & $\begin{array}{l}\text { Dissatisfaction with the } \\
\text { employment conditions, seeking } \\
\text { for flexibility and independence. }\end{array}$ \\
\hline & & $\begin{array}{l}\text { Blanchflower and } \\
\text { Oswald, } 1998\end{array}$ & $\begin{array}{l}\text { - Non-pecuniary benefit } \\
\text { from being their own } \\
\text { boss. }\end{array}$ \\
\hline
\end{tabular}

\footnotetext{
${ }^{1}$ The unemployed and the employees - the main activity forms (The Lithuanian Department of Statistics „Work force, employment and unemployment ' 2010 ")
} 
According to Ashcroft et al. (2009), it should be noted that the "movement from unemployment to self-employment is in principle conceptually different compared with the movement from paid employment to self employment". With reference to the scientific literature, it can be concluded that the unemployed mainly choose self-employment because of the reduced opportunities in the labour market, i.e. selfemployment is often the only solution for the unemployed, especially immigrants or women, to earn a livelihood and not to lose qualification skills when the rate of unemployment in the country is high. The scientific literature often refers to such choice as the "push" effect or forced self-employment because a person is forced to become self-employed by external factors while employee's decision to seek for selfemployment is based on absolutely different factors - "pull" forces (wish to achieve one's objectives, familial wealth, seeking for autonomy and others), which is referred to as classic self-employment.

\section{Analysis of the activity of Lithuanian population during the period of 1998-2011}

During the period of $1998-2011^{2}$, the employees made the biggest part of all active population while the unemployed and the self-employed without employees made slightly smaller proportion. The employers made the smallest part of all active population (see Fig. 1). With the start of the economic decline, the number of the unemployed increased by 2.63 times, the number of the employees and the employers decreased by 0.9 times, and the number of the self-employed decreased by 0.8 times, comparing the data of 2011 and 2008.

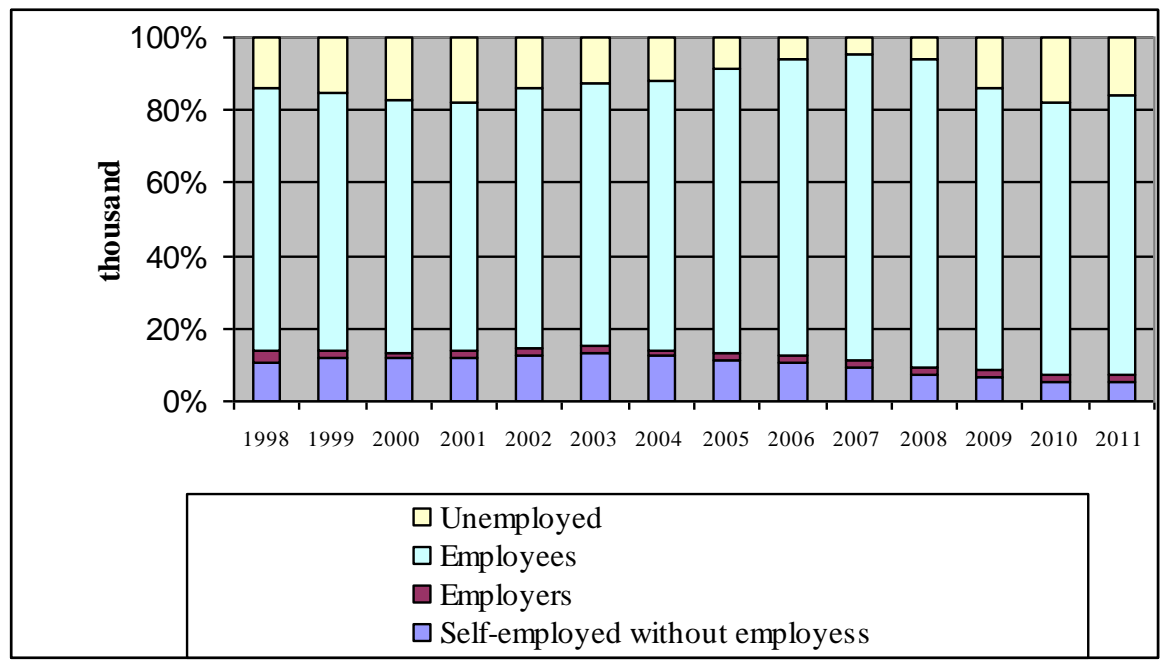

Figure 1. The structure of population activity

Source: The Lithuanian Department of Statistics (further - LDS), Eurostat

With reference to the data of LDS, Eurostat, the features of the self-employed, employees and unemployed are characterised by such main economic and demographic factors as business sector, divided by the sectors of economic activities, gender, age and education.

The analysis of the employment structure (see Figures 2-4) by the sectors of economic activity during the period of 1998-2011 revealed that the distribution of the employees in the sectors of manufacturing, construction ( $\mathrm{C}-\mathrm{F}^{3}$ business sectors), trade, accommodation service and others (G-K business sectors) as well as the sectors of public management, real estate, education and others ( $\mathrm{L}-\mathrm{Q}$ business sectors) is similar. The number of the unemployed is highest in C-F and G-K business sectors. The number of the employees and the unemployed is lowest in agriculture, forestry, fishery, mining and quarrying sectors (A-B business sectors).

${ }^{2}$ The data of 2011 has been presented for I-III quarters (with reference to LDS).

${ }^{3}$ A-B - agriculture, forestry, fishery, mining and quarrying; C-F - manufacturing, electicity, gas, steam supply, water supply, wastewater treatment, waste management, construction; G-K - wholesale and retail, transport and storage, accommodation and catering services, information and communication, financial and insurance activities; L-Q operations with real estate, professional, scientific and technical activities, admistration and maintenance, public management and defence, compulsory social insurance, education, health care and social work. Since 2008, R-T sectors have been added: R- arts, entertainment and recreation, $\mathrm{S}$ - other maintenance sercives, T- households with employed workers. These newly added sectors have been summarized with L-Q. 


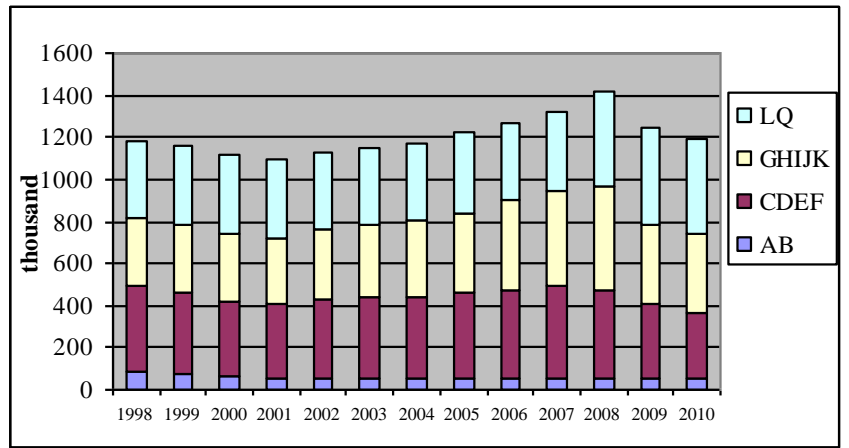

Figure 2. Division of the employees by the sectors of economic activity

Source: LDS

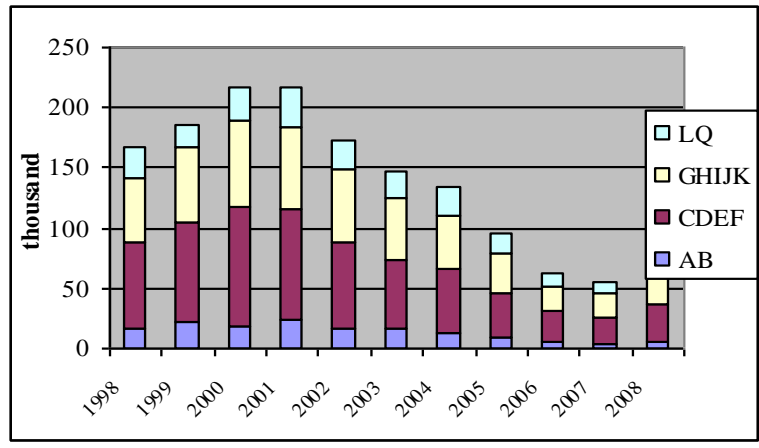

Figure 3. Division of the unemployed by the sectors of economic activity

\section{Source: LDS}

Comparing the division of the self-employed, employees and unemployed by business sectors, it can be seen that agriculture had the highest level of the self-employed, which sharply went down during the period of economic recovery. The self-employed in sectors G-K take the second place by the sectors of economic activity. It can be noticed that the level of self-employment increased in sectors C-F, i.e. construction, manufacturing, electricity supply and others from 2003 to 2009. Possible reasons for this increase are increased consumption, massive purchase of real estate and so forth. Contrary to high level of self-employment in the sectors of real estate, professional, scientific activities and administration, the number of the self-employed was rather small in the sector of public management during the period of 19982008, and the statistical data shows no self-employed people in sectors L-Q during the period of 2009-2010.

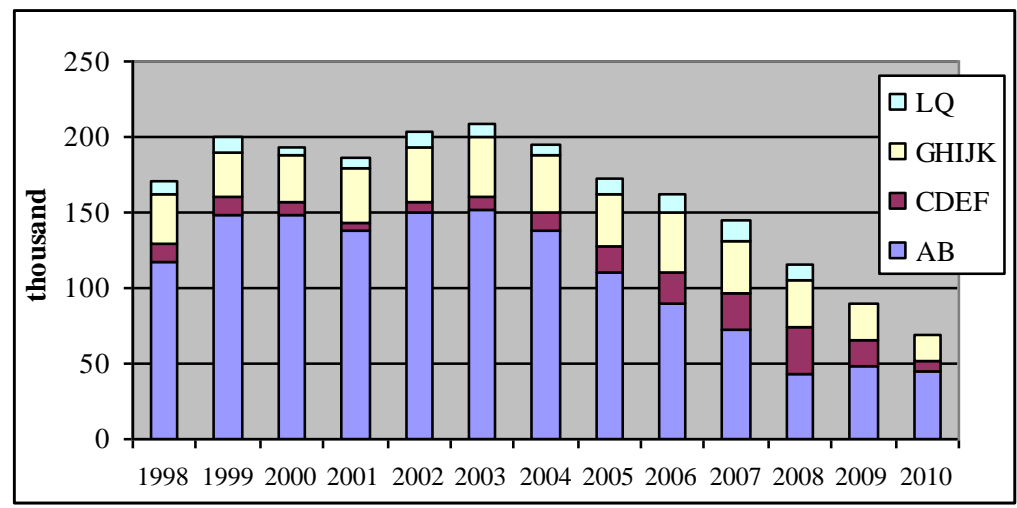

Figure 4. Distribution of the self-employed by the sectors of economic activity Source: Eurostat

Comparing the employees and the unemployed by the data of gender distribution, it can be seen that during the period of 1998-2011, on average women made 41000 employees more than men, and men made 24000 thousand unemployed more than women. Comparing the data of gender distribution of the selfemployed, it can be seen that percentage has hardly changed during the analysed period, i.e. self-employed men have dominated, but the number of the self-employed men is only by 10 per cent higher than the number of the self-employed women.

An interesting fact has been revealed that the number of the self-employed people of older age (65 and older) was higher than the number of the employees of the same age during the period of 1998-2000. This confirms the results of the theoretical research, with reference to which older age of a person is not an obstacle to start-up and develop self-employment. The data of 1998-2010 showed that young people made the highest number of the unemployed and the lowest number of the self-employed in comparison with other age groups. Eurostat provides no data about the number of self-employed young people in 2006 and 20082010.

Education is other important demographical factor of self-employment. Comparing the data of 1998 and 2011, people with secondary and higher education made the highest number (about 30 per cent) of the self-employed. People with pre-primary, primary and lower than secondary education made smaller part of 
the self-employed, and the number of these people decreased by 85.3 per cent from 2003 to 2011 . However, the number of the self-employed people with second stage of tertiary education grew by 19.3 per cent at the same period. In 2001, people with secondary education and first stage of tertiary education made the biggest part (61 per cent) of the employees; people with second stage of tertiary education made 32 per cent and people with pre-primary, primary and lower than secondary education made the smallest part (7 per cent) of the employees. From 2001 to 2010, the number of the employees with second stage of tertiary education increased by 30 per cent, the number of the employees with pre-primary, primary and lower than secondary education decreased by 43 per cent. In 1998, 9 per cent of all employees had pre-primary, primary and lower than secondary education, and in 2010 this number was 4 per cent. The smallest part of the unemployed had completed second stage of tertiary education (this part was 0.7 times lower than the number of the selfemployed with second stage of tertiary education) and pre-primary, primary and lower than secondary education.

Summarising the statistics of Lithuanian employment, unemployment and the data of the determining economic/demographic factors, the following conclusions can be made:

- construction, manufacturing, trade, education, health care, i.e. business sectors C-F, G-K and L-Q have the biggest number of the employees. Possible explanation to this is that sector L-Q is dominated by state-owned enterprises, and sector $\mathrm{C}-\mathrm{F}$ - by large and medium-sized enterprises that employ the biggest number of the employees. If the level of unemployment/economic raise in the country is high, then the number of the unemployed in the sectors mentioned above (except sector L-Q) increases/decreases. Evaluating distribution of the self-employed people by the sectors of economic activity, it can be seen that trade and agriculture are the most attractive sectors for self-employment;

- gender differences in the sphere of employment are obvious: women make the biggest part of the employees while men make the biggest part of the self-employed. The number of the unemployed men is slightly lower than that of the unemployed women;

- the highest level of unemployment and lowest level of self-employment was recorded among young people. During the periods of 1998-2002 and 2009-2010, i.e. the stages of economic recession, more people from the age group of 25-49 were unemployed while during the period of economic recovery/raise from 2003-2008, more people from this age group were self-employed. In the age group of 50-64, the self-employed made 16000 people more than the unemployed during the period of 1998-2008. Unfortunately, in 2009 and 2010, the number of the unemployed in this age group was higher than that of the self-employed.

- education has the influence on the level of employment in the country: people with second and first stages of tertiary education and secondary education have more opportunities in the labour market for becoming both the employees and the self-employed (the level of unemployment among people with second stage of tertiary education is lowest).

\section{Estimation of the strength of the correlation between self-employment level and the number of the employees and the unemployed}

Strength of the linear relationship between variables is usually estimated using Pearson correlation coefficient (Čekanavičius, Murauskas, 2004; Kruopis, 1993; Moore, 2000) which, contrary to other correlation coefficients (Spearman, Kendall Tau-a, Kendall Tau-b, Kendall Tau-c and others), enables estimation of maximum amount of information. In order to assess whether it is expedient to estimate the links of different forms of employment with self-employment, it was primarily verified if there exists any correlation between the number of the unemployed/employees and the number of the self-employed considering the statistical data of the period 1998-2010. Normality condition was met (value p<0.05) after verification of the normality hypotheses

The calculations carried out using the method of Pearson correlation showed the following results of the correlation between the number of the unemployed/employees and the number of the self-employed (see lag values of current years ( 0 ) in bold, Table 2):

- there is strong negative correlation $\left(\mathrm{r}_{\text {employees }}=-0.89\right)$ between the number of the employees and the number of the self-employed;

- there is strong positive correlation $\left(\mathrm{r}_{\text {unemployed }}=0.74\right)$ between the number of the unemployed and the number of the self-employed. 
Strong negative correlation between the number of the employees and the number of the selfemployed (the number of the self-employed decreases when the number of the employees increases) proposes that the results of the empirical research do not confirm the theoretical motives of self-employment choice made by the employees (wish to achieve one's objectives, familial wealth and others). With reference to the calculation results, self-employment in Lithuania is an alternative in case of unemployment. This presumption is based with strong positive correlation between the number of the unemployed and the number of the self-employed, i.e. when the rate of unemployment increases and there are fewer opportunities to find employment, the level of self-employment in the country increases. From this point of view, Lithuania can be treated as a country where entrepreneurship is influenced by external factors (unemployment, income loss) more than by internal personal factors (implementation of objectives, dreams and so forth).

Further analysis included the research of the correlation between the demographical characteristics of the self-employed and the unemployed (Startiene, Remeikiene, 2009) regarding gender, different age intervals (the choice of the age intervals was determined by the Eurostat data classification principles), economic activities and education.

Calculations of cross-correlation coefficient revealed strong interdependence between the selfemployed and the unemployed people which proposes that:

- there exists a link between the unemployed and the self-employed people of different age groups, but the biggest correlation has been estimated in the age group of 25-49 because the unemployed belonging to this age group are the most inclined to start-up self-employment (they have accumulated enough experience, capital, knowledge);

- medium strong positive correlation ( $\mathrm{r}_{\text {unemployed with pre-primary, primary and lower than secondary education }}=0.76$ ), estimated between the number of the unemployed with pre-primary, primary and lower than secondary education and the number of the self-employed proposes that the unemployed with preprimary, primary and lower than secondary education can look for the ways to escape unemployment more intensively than the unemployed with secondary/first stage tertiary or second stage tertiary education and become the self-employed;

- stronger correlation between the number of the unemployed women and the number of the selfemployed women $\left(\mathrm{r}_{\text {unemployed women }}=0.76\right)$ than between the number of the unemployed men and the number of the self-employed men $\left(\mathrm{r}_{\text {unemployed men }}=0.65\right)$ proposes that the unemployed women are more inclined to become self-employed than the unemployed men;

- the number of the self-employed in such business sectors as agriculture, manufacturing, construction and others has strong correlation with the number of the unemployed in these sectors.

Foreign scientists (Golpe, Stel, 2007; Thurik, Verheul, 2002; Baptista, Thurik, 2007 and others) state that looking for correlation links between the factors determining entrepreneurship (in this case - selfemployment), it is recommendable to consider a long time shift because even if a person has made a decision to become self-employed, self-employment start-up or development can take several years. With reference to scientists' recommendations, the method of cross-correlation was used to calculate correlation coefficient $r_{k}$ (Box, Tiao, 1975). Considering the four years ${ }^{4}$ time shift, the interdependence between the number of the self-employed and the number of the unemployed has been estimated regarding gender, age, business sector and education during the period of 1998-2010.

Table 2 shows only the results which are statistically important, i.e. which correlate with the probability of 95 per cent.

\footnotetext{
${ }^{4}$ Year zero or current year means that during the period of 1998-2010 the values of $\mathrm{x}$ were compared with the corresponding values of $y$, i.e. how the number of the unemployed could affect the level of self-employment during current year. " +1 " means time shift one year ago, when the values of $x$ during the period 1998-2009 were compared with the values of y during the period 1999-2010, i.e. how variation of the number of the unemployed previous year could affect variation of the level of unemployment the next year. " +2 " means time shift two years ago, when the values of $x$ during the period 1998-2008 were compared with the values of $y$ during the period 2000-2010, i.e. how variation of the number of the unemployed aged from 25-49 two years ago could affect variation of the level of unemployment subsequent years and so on. "-1" means time shift one year forward, i.e. the values of y during the period of 1998-2009 were compared with the values of $x$ during the period 1999-2010.
} 
Table 2. Cross-correlation coefficients between the number of the self-employed and the number of the unemployed

\begin{tabular}{|c|c|c|c|}
\hline $\begin{array}{c}\text { Lag } \\
\text { value }\end{array}$ & Dependent variable $(y)$, thousands & Independent variable $(\mathbf{x})$, thousands & $\begin{array}{c}\text { Correlat } \\
\text { ion }\end{array}$ \\
\hline $\mathbf{0}$ & The self-employed & The employees & $-0,88969$ \\
\hline $\mathbf{0}$ & The self-employed & The unemployed & 0,73751 \\
\hline 1 & The self-employed & The unemployed & 0,82401 \\
\hline 2 & The self-employed & The unemployed & 0,68296 \\
\hline 1 & The self employed of the age $15-24$ & The unemployed of the age $15-24$ & 0,64640 \\
\hline $\mathbf{0}$ & The self employed of the age $15-24$ & The unemployed of the age 15-24 & 0,65117 \\
\hline $\mathbf{0}$ & The self-employed of the age $25-49$ & The unemployed of the age $25-49$ & 0,76579 \\
\hline 1 & The self-employed of the age $25-49$ & The unemployed of the age $25-49$ & 0,83501 \\
\hline 2 & The self-employed of the age $25-49$ & The unemployed of the age $25-49$ & 0,68292 \\
\hline $\mathbf{0}$ & The self-employed of the age 50-64 & The unemployed of the age 50-64 & $\mathbf{0 , 7 7 2 4 7}$ \\
\hline 1 & The self-employed of the age 50-64 & The unemployed of the age 50-64 & 0,81442 \\
\hline 4 & The self-employed of the age 65 and older & The unemployed of the age 65 and older & 0,70652 \\
\hline 3 & The self-employed of the age 65 and older & The unemployed of the age 65 and older & 0,81697 \\
\hline $\mathbf{0}$ & The self-employed women & The unemployed women & $\mathbf{0 , 7 8 4 0 1}$ \\
\hline 1 & The self-employed women & The unemployed women & 0,80460 \\
\hline 2 & The self-employed women & The unemployed women & 0,61682 \\
\hline $\mathbf{0}$ & The self-employed men & The unemployed men & 0,65513 \\
\hline 1 & The self-employed men & The unemployed men & 0,79709 \\
\hline 2 & The self-employed men & The unemployed men & 0,69478 \\
\hline $\mathbf{0}$ & $\begin{array}{l}\text { The self-employed with pre-primary, primary } \\
\text { and lower than secondary education }\end{array}$ & $\begin{array}{l}\text { The unemployed with pre-primary, primary and } \\
\text { lower education }\end{array}$ & $\mathbf{0 , 7 6 9 5 8}$ \\
\hline 1 & $\begin{array}{l}\text { The self-employed with pre-primary, primary } \\
\text { and lower than secondary education }\end{array}$ & $\begin{array}{l}\text { The unemployed with pre-primary, primary and } \\
\text { lower education }\end{array}$ & 0,82407 \\
\hline 2 & $\begin{array}{l}\text { The self-employed with pre-primary, primary } \\
\text { and lower than secondary education }\end{array}$ & $\begin{array}{l}\text { The unemployed with pre-primary, primary and } \\
\text { lower education }\end{array}$ & 0,67336 \\
\hline-4 & $\begin{array}{l}\text { The self-employed with secondary and higher } \\
\text { education }\end{array}$ & $\begin{array}{l}\text { The unemployed with secondary and higher } \\
\text { education }\end{array}$ & $-0,62247$ \\
\hline-3 & $\begin{array}{l}\text { The self-employed with secondary and higher } \\
\text { education }\end{array}$ & $\begin{array}{l}\text { The unemployed with secondary and higher } \\
\text { education }\end{array}$ & $-0,67272$ \\
\hline 2 & $\begin{array}{l}\text { The self-employed with secondary and higher } \\
\text { education }\end{array}$ & $\begin{array}{l}\text { The unemployed with secondary and higher } \\
\text { education }\end{array}$ & 0,61779 \\
\hline $\mathbf{0}$ & The self-employment in business sectors A-B & The unemployment in business sectors A-B & $-0,82467$ \\
\hline 1 & The self-employment in business sectors A-B & The unemployment in business sectors A-B & 0,84444 \\
\hline 2 & The self-employment in business sectors A-B & The unemployment in business sectors A-B & 0,63259 \\
\hline $\mathbf{0}$ & The self-employment in business sectors C-F & The unemployment in business sectors C-F & $-0,81717$ \\
\hline
\end{tabular}

Summarizing the results obtained using calculation methods of Pearson correlation, cross-correlation and determination coefficient, the following conclusions can be made:

1) the results of the calculations showed that both the employees and the unemployed have opportunities to start-up self-employment. It has been established that in the case of Lithuania, the employees and the unemployed choose self-employment because of the same reasons which are theoretically referred to as self-employment out of necessity, but not self-employment out of the opportunity in the labour market;

2) the fact that both the employees and the unemployed are inclined to become self-employed due to high rate of unemployment and the necessity to earn a livelihood, has limited the sample of the research, so it included only the analysis of the correlation between the unemployed and the selfemployed;

- the unemployed women $\left(\mathrm{r}_{\text {unemployed women }}=0.78 ; \mathrm{R}^{2}=0.615\right)$ have higher potential to start-up self-employment than the unemployed men $\left(r_{\text {unemployed men }}=0.655 ; R^{2}=0.43\right)$. Possible reasons: greater discrimination of women in the labour market, more flexible working hours, bigger responsibility for childcare; 
- the unemployed with pre-primary, primary or lower than secondary education are more inclined to self-employment than that with higher education $\left(\mathrm{r}_{\text {unemployed with pre-primary, primary or lower }}\right.$ than secondary education $=0.77$;

- age range of the unemployed seeking for self-employment is quite wide, i.e. it includes the unemployed aged from 15 to 65 years and older;

- the calculations confirmed the statistical data that the biggest number of the self-employed work in business sectors A-B: $r_{k}$ unemployed $=-0.82$, during current year, $r_{k}$ unemployed $=0.84$, with time shift of 1 year, $r_{k}$ unemployed $=0.63$, with time shift of 2 years. It can be concluded that an unemployed person seeking to establish himself as a self-employed in agricultural sector takes several years to embody his ideas.

\section{Conclusions}

Summarizing, the following conclusions can be made:

1) The theoretical research revealed that people attributed to different forms of employment are motivated to start-up self-employment by different reasons. "Push" forces such as income loss, discrimination, obstacles in the labour market, subsidies for business start-up motivate the unemployed to try to start-up self-employment while "pull" forces such as personal profit, familial wealth, autonomy, sense of happiness, recognition of opportunities motivate the employees to try themselves in "the sphere where they could experience the greatest satisfaction".

2) The analysis of the statistical data in Lithuania during the period of 1998-2011 showed that the employees take the biggest part in the structure of population activity; the second place is occupied by the unemployed and the number of the self-employed is the smallest. It was established that the employees are most inclined to work in such business sectors as construction, manufacturing, trade, education and health care while the self-employed choose work in agriculture and trade sectors. Gender, education and age also have influence on personal decision to choose self-employment. The analysis of the data revealed that people with secondary or first and second stage of tertiary education aged from 25 to 64 are potential work force for both hired work and self-employment. The highest unemployment prevails among the youth and the people with pre-primary, primary or lower education and it is more often recorded among men than among women.

3) Mathematical statistical methods of the analysis helped to reveal that self-employment in Lithuania is related to the opportunity to escape unemployment, i.e. people become self-employed only in order to earn a livelihood. Lithuania can be treated as the country where entrepreneurship is influenced by external factors (unemployment, income loss) more than by internal factors (objectives, implementation of dreams). The research revealed that the main demographical characteristics of the unemployed seeking to become the self-employed are as follows: by age range - the unemployed of the age 15-64, by education - the unemployed with pre-primary, primary and lower education, by gender - the unemployed women (the unemployed men have fewer possibilities), by business sector - sectors A-B.

\section{References}

1. Andersson P. \& Wadensjö E. (2007). Do the unemployed become successful entrepreneurs? 27, 7, 604-626.

2. Ashcroft B., Holden D., Low K. (2009). Entrepreneurial interest, vision and self-employment choice decision in UK regions. Regional Studies, 43, 8, 1075-1090.

3. Baptista R., Thurik R. (2007). The relationship between entrepreneurship and unemployment: Is Portugal an outlier? Technological Forecasting\&Social Change, vol. 74, no. 1, 75-89.

4. Benz M. and Frey B. (2004). Being independent raises happiness at work. Swedish Economic Policy Review, 11, 2, 95-134.

5. Benz M. and Frey B. (2008). Being independent is a great thing - subjective evaluations of self-employment and hierarchy. Economica, 75, 298, 362-383.

6. Berzinskiene D., Juozaitiene L. (2011). Impact of Labour Market Measures on Unemployment. Inzinerine Ekonomika-Engineering Economics, 22(2), 186-195.

7. Binder M., Coad A. (2012). Life satisfaction and self-employment: a matching approach. Small Bus Econ (in press). doi: 10.1007/s11187-011-9413-9. 
8. Blanchflower D.G. and Oswald A. J. (1998). What makes an entrepreneur? Journal of LaborEconomics, 16, 1, 2660 .

9. Blume K., et. al. (2009). Labour market transitions of immigrants with emphasis on marginalization and selfemployment. J Popul Econ, 22, 881-908.

10. Box G. E. P., Tiao G. C. (1975). Intervention Analysis with Applications to Economic and Environmental Problems, JASA, 70, 70-79.

11. Caliendo M. \& Kritikos A. (2010). Start-ups by the unemployed: characteristics, survival and direct employment effects. Small Business Economics, 35, 71-92.

12. Caliendo M., Kritikos A (2009). I Want to, But I Also Need to. Start-Ups Resulting from Opportunity and Necessity. Discussion Paper No. 4661, December 2009, IZA.

13. Carree M. A., et. al. (2007). Does Self-Employment reduce Unemployment? Discussion Papers on Entrepreneurship, Growth and Public Policy, 1-18.

14. Cassar G. (2007). Money, money, money? A longitudinal investigation of entrepreneur career reasons, growth preferences and achieved growth. Entrepreneurship and Regional Development, 19(1), 89-107.

15. Clark K., Drinkwater S. (2010). Patterns of ethnic self-employment in time and space: evidence from British Census microdata. Small Bus Econ 34, 323-338.

16. Čekanavičius V., Murauskas G. (2004). Statistika ir jos taikymai, 2 dalis. Vilnius: TEV, p. 272.

17. Darbo jëga, užimtumas ir nedarbas' 2010. Lietuvos Statistikos Departamentas, ISSN 2029-3712, Vilnius.

18. Dawson C., Henley A., Latreille P. (2009). Why do individuals choose self-employment? Discussion Paper, no. 3974, 42. [interaktyvus] [žiūrèta 2009-05-09]. Prieiga per internetą: http: / / ftp.iza.org / dp3974.pdf.

19. Dunn T. \& Holtz-Eakin D. (2000). Financial capital, human capital, and the transition to self-employment: Evidence from intergenerational links. Journal of Labor Economics, 18(2), 282-305.

20. Elfenbein D. W., Hamilton B. H., \& Zenger T. R. (2010). The small firm effect and the entrepreneurial spawning of scientists and engineers. Management Science, 56(4), 659-681.

21. Evans D. S. \& Jovanovic B. (1989). An estimated model of entrepreneurial choice under liquidity constraints. Journal of Political Economy, 97(4), 808-827.

22. Evans D. S. \& Leighton L. S. (1989). Some empirical aspects of entrepreneurship. American Economic Review, 79(3), 519-535.

23. Fölster S. (2000). Do entrepreneurs create jobs? Small Business Economics, 14, 137-148.

24. Georgellis Y.; Wall H. (2005). Gender differences in Self-employment. International Review of Applied Economics, vol. 19, no. 3, 321-342.

25. Golpe A., Stel A. (2007). Self-Employment and Unemployment in Spanish Regions in the Period 1979-2001. Jena Economic Research Papers, 2007-021, 1-13.

26. Hammarstedt M. (2004). Self-employment among immigrants in Sweden - an analysis of intragroup differences. Small Business Economics, 23, 115-126.

27. Hammarstedt M. (2009). Predicted earnings and the propensity for self-employment: evidence from Sweden. International Journal of Manpower, 30, 4, 349-359.

28. Hessels J. \& Gelderen van M. \& Thurik R. (2008). Drivers of entrepreneurial aspirations at the country level: the role of start-up motivations and social security. Int Entrep Manag J (2008) 4:401-417.

29. Jacobs G. (2007). An occupational choice model for developing countries. [interaktyvus] [žiūrèta 2008-10-22]. Prieiga per internetą: http: / / www.iza.org / conference_files / worldb2007 / jacobs_g3384.pdf.

30. Johansson E. (2000). Determinants of self-employment duration - evidence from Finnish micro-data. Essays on Economics and Business Administration, Helsinki, Ekonomi och Samhäll, 85, 30.

31. Kawaguchi D. (2008). Self-employment rents: Evidence from job satisfaction scores. Hitotsubashi Journal of Economics, 49(1), 35-45.

32. Kruopis J. (1993). Matematinè statistika. Vilnius: Mokslo enciklopedijų leidykla, p.416.

33. Lofstrom, M. (2002). Labor market assimilation and the self-employment decision of immigrant entrepreneurs. Journal of Population Economics, 15, 83-114.

34. Milán J. M., Hessels J., Thurik R., Aguado R. (2011). Determinants of job satisfaction: a European comparison of self-employed and paid employees. Small Bus Econ (in press). doi: 10.1007/s11187-011-9380-1.

35. Moore D. S. (2000). Statistics: Concepts and Controversies, Fifth Edition, New York: W.H. Freeman \& Company.

36. Muehlberger U. (2007). Dependent Self-Employment. Palgrave Macmillan, 217 p.

37. Parker S. C. (2004). The Economics of Self-employment and Entrepreneurship. Cambridge University Press, 323 p. 
38. Pukeliene V., Starkauskiene V. (2011). Quality of Life: Factors Determining its Measurement Complexity. Inzinerine Ekonomika-Engineering Economics, 22(2), 147-156.

39. Ritsilä J., Tervo H. (2002). Effects of Unemployment on New Firm Formation: Micro-Level Panel Data Evidence from Finland. Small Business Economics, 19, 31-40.

40. Shane S., Locke E., \& Collins C. J. (2003). Entrepreneurial motivation. Human Resource Management Review, 13(2), 257-280.

41. Startiene G., Remeikiene R. (2009). The influence of demographical factors on the interaction between entrepreneurship and unemployment. Inzinerine Ekonomika-Engineering Economics, 4 (64), 60-70.

42. Thurik A. R., Carree M. A., van Stel A. J. \& Audretsch D. B. (2008). Does self-employment reduce unemployment? Journal of Business Venturing (in press).

43. Thurik R., Verheul I. (2007). The relationship between Entrepreneurship and Unemployment: The Case of Spain. [interaktyvus] [žiūrèta 2009-03-11]. Prieiga per internetą: http: / / people.few.eur.nl / verheul / hvi_6.pdf.

44. Tervo H. (2008). Self-employment transitions and alternation in Finnish rural and urban labour markets. Regional Science, vol. 87, no. 1, 55-76.

45. Verheul I., Stel A., Thurik, R. (2006). Explaining female and male entrepreneurship at the country level. Entrepreneurship and Regional Development, 155-163.

46. Uusitalo R. (2001). Homo entreprenaurus? Applied Economics, 33(13), 1631-1638. 